\title{
SUICIDAS FELIZES E OUTROS MITOS: OS IMPLÍCITOS DO DISCURSO DA INDÚSTRIA DA CARNE PARA NORMATIZAÇÃO DO CONSUMO E ANULAÇÃO DA EMPATIA
}

\author{
HAPPY SUICIDES AND OTHER MYTHS: THE IMPLICATIONS OF THE MEAT INDUSTRY SPEECH FOR \\ CONSUMPTION NORMALIZATION AND ANNULMENT OF EMPATHY
}

Fernando Simões Antunes Juniorl, Ernani Cesar de Freitas²

\author{
Recebido em: 31 de agosto de 2017 \\ Aprovado em: 25 de novembro de 2017 \\ Sistema de Avaliação: Double Blind Review \\ RCO | a. 10 | v. 1 | p. 101-119 | jan./jun. 2018 \\ DOI: https://doi.org/10.25112/rco.vli0.1323
}

\begin{abstract}
RESUMO
O presente estudo pretende estabelecer, de forma transversal e exploratória, interfaces entre alguns fundamentos teóricos da comunicação, da neurociência e da análise de discurso. A intenção é compreender como construtos simbólicos da propaganda de alimentos se utilizam de estratégias discursivas para eliciar emoções e anular processos empáticos de forma a induzir e/ou favorecer o consumo de carne e seus derivados. Tal análise se justifica a partir de estudos recentes que mostram a importância das emoções e da empatia na formação de crenças, comportamentos e hábitos de consumo. A partir da análise de peças publicitárias produzidas pelas marcas Sadia, Seara e Friboi, e com base em descobertas recentes da neurociência, assume-se neste estudo que o processo empático é o primeiro estágio do ato comunicativo, que está ligado à capacidade de reconhecer estados emotivos no outro a partir de referências universais (inatas) e aprendidas (condicionadas). O marco teórico é constituído por pressupostos de Charaudeau (2004, 2016), Damásio (2000/2012), Ekman (2011), Krznaric (2015), Jung (1991/2011), entre outros, que vão ajudar na elaboração de circuitos que explicam a função das emoções na ativação e/ou anulação do processo empático por meio do ato de linguagem e do discurso na comunicação publicitária. Com isto, busca-se demonstrar a capacidade de manifestar e de perceber o sentir através da linguagem, de maneira a interferir na organização da mente, tanto em seus processamentos conscientes quanto inconscientes, afetando a cognição, o aprendizado e os hábitos de consumo.
\end{abstract}

Palavras-chave: Comunicação. Discurso. Emoções. Empatia. Consumo.

\begin{abstract}
The present study aims to establish, in a transversal and exploratory way, interfaces between some theoretical foundations of communication, neuroscience and discourse analysis. The intention is to understand how symbolic constructs of food advertising use discursive strategies to elicit emotions and negate empathic processes in order to induce and / or favor the consumption of meat and its derivatives. This analysis is justified by recent studies that show the importance of emotions and empathy in the formation of beliefs, behaviors and consumption habits. Based on the analysis of advertising pieces produced by the brands Sadia, Seara and Friboi, and based on recent discoveries of neuroscience, it is assumed in this study that the empathic process is the first stage of the communicative act, which is linked to the ability to recognize states Emotional in the other from universal (innate) and learned

\footnotetext{
${ }^{1}$ Doutor em Comunicação Social pela Pontifícia Universidade Católica do Rio Grande do Sul (Porto Alegre/Brasil). E-mail: feuantunes@gmail.com.

${ }^{2}$ Doutor em Letras pela Pontifícia Universidade Católica do Rio Grande do Sul (Porto Alegre/Brasil). Professor na Universidade de Passo Fundo (Passo Fundo/Brasil). E-mail: ecesar@feevale.br.
} 
(conditioned) references. The theoretical framework is constituted by the assumptions of Charaudeau (2004, 2016), Damásio (2000/2012), Ekman (2011), Krznaric (2015), Jung, among others, that will help in the elaboration of circuits that explain the function of the emotions in the activation and / or annulment of the empathic process through the act of language and the discourse in the advertising communication. In this way, the aim is to demonstrate the ability to express and perceive feeling through language, so as to interfere in the organization of the mind, both in its conscious and unconscious processes, affecting cognition, learning and consumption habits.

Keywords: Communication. Speech. Emotions. Empathy. Consumption.

\section{INTRODUÇÃO}

O filósofo escocês John Oswald, ainda no século XVIII, defendia a ideia de que a compaixão e a misericórdia eram sentimentos inatos do ser humano. Corroborando a tese de que o homem era bom por natureza, a exemplo do que acreditava seu contemporâneo Jean Jacques Rousseau, Oswald chega a tal concepção ao perceber a relação do homem com os animais. Com o argumento de que, se todo ser humano tivesse que testemunhar a morte do animal que come, a dieta vegetariana seria bem mais popular, o teórico questiona como a divisão do trabalho advindo da revolução industrial levou o homem moderno a consumir produtos de origem animal sem passar pela experiência que chama de "alerta para as sensibilidades naturais do Ser Humano". Uma divisão cartesiana que brutalizou e dessensibilizou o ser humano, acomodando-o num viver coletivo isolacionista e acrítico (OSWALD, 2000).

Passados mais de dois séculos desde que Oswald escreveu "The Cry of Nature or an Appeal to Mercy and Justice on Behalf of the Persecuted Animals"3, os animais receberam direitos, deixaram de ser "coisas" para se tornarem "sujeitos" em alguns países, e recentemente foram declarados seres dotados de consciência por diversos neurocientistas na famosa "Declaração de Cambridge"4. O manifesto tem as assinaturas de doutores de instituições de renome como Caltech, MIT e Instituto Max Planck.

Trata-se do resultado de uma compilação de inúmeras pesquisas na área, e representa um posicionamento inédito sobre a capacidade de outros seres perceberem sua própria existência e o mundo ao seu redor.

Em entrevista ao site de VEJA ${ }^{5}$, Philip Low, criador do iBrain, o aparelho que recentemente permitiu a leitura das ondas cerebrais do físico Stephen Hawking, e um dos articuladores do movimento, explica que nos últimos 16 anos a neurociência descobriu que as áreas do cérebro que distinguem seres humanos de outros animais não são as que produzem a consciência. "As estruturas cerebrais responsáveis pelos processos que geram a consciência nos humanos e outros animais são equivalentes", diz ele, ao que complementa: "concluímos então que esses animais também possuem consciência" (PIRES, 2012).

Reconhecer consciência nos animais talvez explique porque nos afeiçoamos a eles. Enxergar traços de personalidade e, portanto, de humanidade em outras espécies amplia nossa capacidade mimética em relação a elas (KRZNARIC, 2015; FELIPE, 2014). A dinâmica do espelho sai da esfera das semelhanças físicas para se transferir às semelhanças emocionais e sentimentais. Nossa natureza empática passa então a ser confrontada com as culturas e tradições que afirmam que também é de nossa

\footnotetext{
${ }^{3}$ Tradução: O Choro da Natureza ou um apelo à misericórdia e à justiça em nome dos animais perseguidos.

${ }^{4}$ Disponível em: <http://fcmconference.org/img/CambridgeDeclarationOnConsciousness.pdf>. Acesso em: 25 jun. 2017.

${ }^{5}$ Disponível em: <http://veja.abril.com.br/ciencia/nao-e-mais-possivel-dizer-que-nao-sabiamos-diz-philip-low/>. Acesso em:

20 abr. 2017.
} 
natureza comer e explorar animais. Tal contradição nos coloca em um estado de esquizofrenia coletiva, onde optamos por domesticar algumas espécies e delegamos o fardo da servidão e exploração a outras.

$\mathrm{Na}$ cultura ocidental, vacas, porcos, galinhas e peixes são espécies para consumo, ao mesmo tempo em que cães, gatos e aves de rapina são considerados animais de estimação. Já em alguns países do Oriente a lógica especista ${ }^{6}$ se inverte (FELIPE, 2014). Em algumas localidades da Índia, por exemplo, a vaca é considerada um animal sagrado para algumas culturas que seguem o hinduísmo. Enquanto que na China, cães são vistos como animais para consumo em muitos povoados do sul daquele país. Na cidade de Yulin, província de Guangxi, por exemplo, mais de 10 mil cães são mortos anualmente para comemorar o solstício de verão e também alimentar o turismo em torno da tradição (Figura 1).

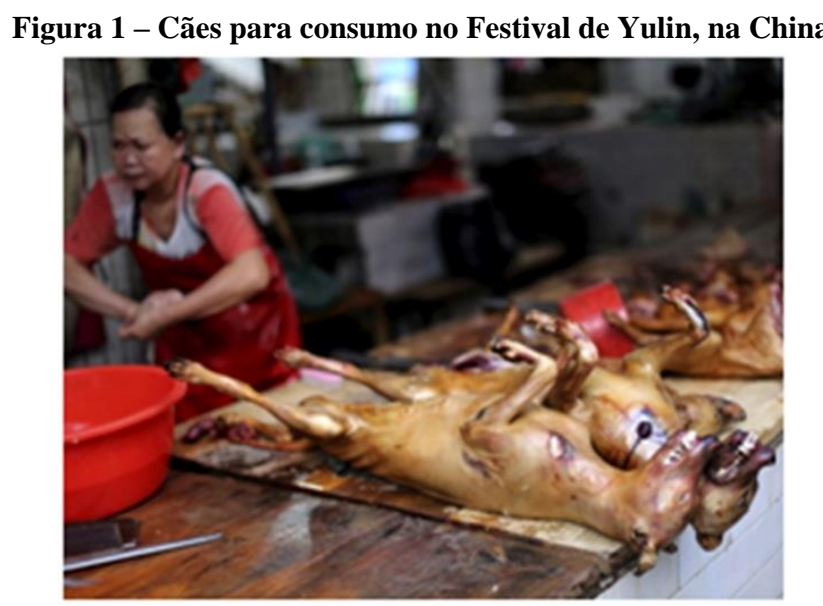

Fonte: Portal G1 $^{7}$

A predileção por domesticar algumas espécies e consumir outras mostra que a ativação ou anulação dos mecanismos empáticos se dá por meio da disseminação da cultura e da tradição, ou seja, é algo que precisa ser ensinado e aprendido. Para as crianças expostas a desenhos animados estrelados por animais, como as personagens Galinha Pintadinha ou Peppa Piggy, fica difícil compreender como é possível comermos aqueles que nos são amigos no imaginário infantil.

Um vídeo que viralizou na internet em $2013^{8}$ estrelado por um menino de Brasília de apenas três anos evidencia uma das teorias da pré-disposição empática do ser humano a "tudo que tem um rosto" (ANTUNES JUNIOR, 2016). Na gravação, a criança resiste a comer um prato de nhoque com polvo alegando que as pessoas têm que cuidar dos animais em vez de comê-los. No desenrolar da conversa, o menino de nome Luiz Antônio (Figura 2) chega a questionar a mãe, autora da gravação, onde estava a cabeça do bicho e se ele seria de verdade. "Não gosto que eles morrem. Eu gosto que eles ficam em pé", diz a criança. $\mathrm{O}$ vídeo já foi traduzido para os idiomas inglês, italiano, espanhol, árabe e chinês, e alcançou mais de 5 milhões de visualizações, o que levou o jovem protagonista a estrelar reportagens e matérias de grandes portais de notícias e de emissoras de televisão.

\footnotetext{
${ }^{6}$ Termo usado para se referir à discriminação que envolve atribuir a animais sencientes diferentes valores e direitos baseados na sua espécie (JOY, 2015).

${ }^{7}$ Disponível em: <http://g1.globo.com/natureza/noticia/2015/06/yulin-o-polemico-festival-chines-em-que-se-comem-10milcachorros.html>. Acesso em: 20 abr. 2017.

${ }^{8}$ Disponível em: <http://g1.globo.com/distrito-federal/noticia/2013/06/menino-do-df-que-se-negou-comer-polvo-ja-montoujogo-de-500-pecas.html>. Acesso em: 20 abr. 2017.
} 


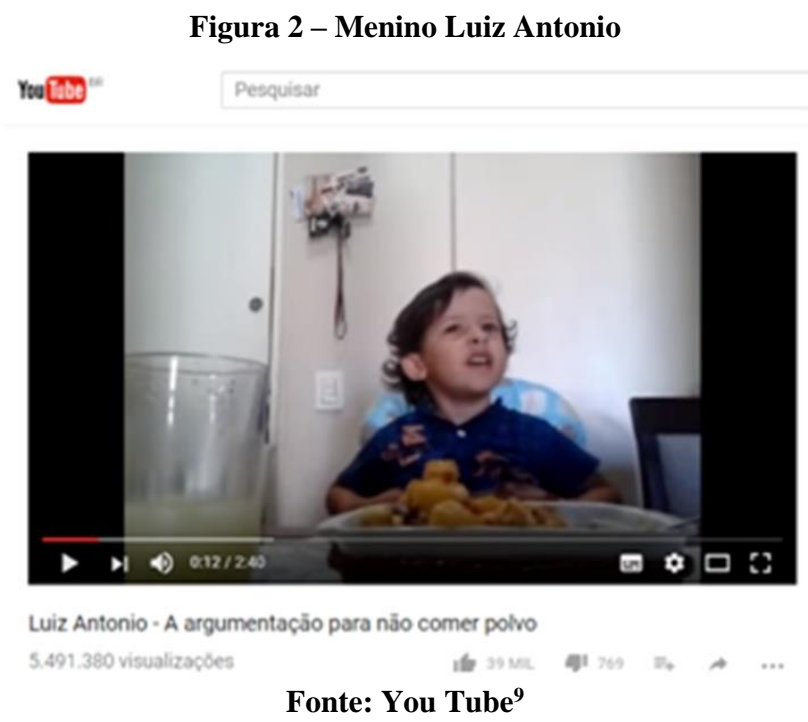

No entanto, qualquer movimento empático pró animalista torna-se um paradoxo diante dos 56 bilhões de animais mortos anualmente pela indústria de alimentos. Com base nas estatísticas da FAO (Food and Agriculture Organization of the United Nations), o Secretariado da União Vegetariana Europeia (EVU), num comunicado recente, mostrou que, somente nos abatedouros, o número de animais mortos anualmente equivale a sete vezes a população humana da Terra (FELIPE, 2014). Trata-se, levando-se em conta a Declaração de Cambridge, do maior genocídio de seres conscientes já registrado na história.

Os números foram estabelecidos a partir de relatórios provenientes de mais de 210 países, levando-se em consideração que alguns países e territórios não fornecem dados. Excluem-se desta conta os animais de criação extensiva (geralmente para consumo doméstico) assim como os que são alvo da caça, difíceis de contabilizar por não haver qualquer tipo de controle. Os animais explorados pela indústria de pele, que chega a matar 200 animais para a produção de um único casaco, também não entraram na contagem da FAO (FELIPE, 2014).

Tal contradição nos leva a buscar entender como funcionam os mecanismos responsáveis pela empatia no ser humano, e nos leva a questionar como a cultura e a sociedade distorcem tais mecanismos a ponto de anular a sensibilidade pelo sofrimento dos animais, tão comum em crianças e por vezes rara nos adultos.

Neste artigo, parte-se, do pressuposto de que existe uma relação de forças simbólicas hierarquizadas e institucionalizadas que alimentam uma ideologia especista nos construtos simbólicos midiatizados. Tal ideologia é reforçada pela eliciação de emoções específicas (EKMAN, 2011; DAMÁSIO, 2012) que vão resultar na anulação ou distorção da empatia (KRZNARIC, 2015; ANTUNES JUNIOR, 2016), com objetivo de favorecer o consumo de produtos de origem animal, sem que haja qualquer reflexão sobre os conflitos éticos que permeiam este hábito.

O marco teórico, portanto, apresenta conceitos sobre gatilhos emocionais de Ekman (2011) em interface com a cognição emocional de Damásio (2000, 2012), a eliciação empática de Krznaric (2015), além da perspectiva semiolinguística de Charaudeau $(2004,2016)$ no que diz respeito às estratégias discursivas e à intencionalidade psico-sócio-discursiva que determina a expectativa do ato de linguagem do sujeito falante, ao que chama de visadas.

\footnotetext{
${ }^{9}$ Idem ao anterior
} 
Diante da proposta, elege-se como corpus três peças publicitárias veiculadas entre 2013 e 2014, sendo uma da Friboi, uma da Seara e outra da Sadia. A pesquisa é de natureza exploratória com procedimentos técnicos bibliográficos e documentais, mediante abordagem qualitativa. Neste recorte, busca-se compreender como a indústria de alimentos se utiliza de estratégias discursivas para anular mecanismos empáticos inconscientes de forma a favorecer o consumo de produtos de origem animal.

\section{A NATUREZA EMPÁTICA ANTE O MISE EN SCÈNE DO ATO DE LINGUAGEM}

A empatia é considerada uma das engrenagens centrais do vibrar em conjunto social. É por ela que experienciamos emoções e sentimentos alheios sem necessariamente viver a experiência fundante de forma direta. É um mecanismo que utiliza nossa capacidade cerebral de trabalhar com memórias e projeções, eliciado quando nos identificamos com o drama do outro e que nos impele a buscar uma ação a partir desta identificação (BATESON, 1987). No mise en scène comunicativo (Figura 3) de Charaudeau (2016), a empatia ocorre quando o EU Comunicante (EUc) e o TU Interpretante (TUi) estão alinhados às projeções do EU enunciador (EUe) e do TU destinatário (TUd), de forma que ocorra uma sinergia de ideias, sensações e sentimentos ante o ato comunicativo tanto no espaço interno quanto no espaço externo da fala configurada. A carga emocional do EUe alcança a percepção do TUi, de forma a provocar uma reação empática, onde o TUi não considera mais apenas as próprias necessidades, mas também as ncessidades do EUe.

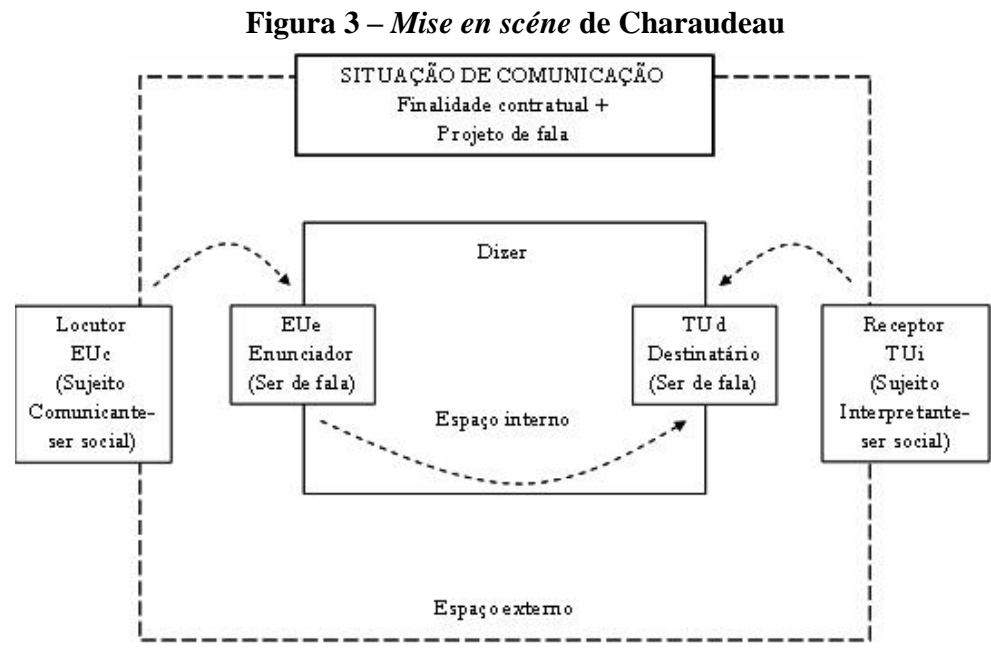

Fonte: Charaudeau (2016, p. 52)

É deste processo empáticoque se desenvolve a compaixão, e está diretamente relacionado ao desejo de viver sonhos que não são originalmente nossos e aderir a diferentes ideologias que melhor se encaixam em nosso enredo cognitivo.A capacidade de buscar uma informação armazenada na memória a partir da vivência de uma emoção é uma das bases do mecanismo acionador da empatia. Uma das formas de categorização de memórias por parte do inconsciente está fortemente embasada nas emoções.

Fritz Perls (1981), idealizador da Gestalt-terapia, para descobrir a origem dos traumas de seus pacientes, solicitava que eles dirigissem o foco da atenção às sensações físicas provocadas pela emoção a ser trabalhada. Quando os questionava se eram capazes de lembrar de outros momentos da vida aonde tinham vivido aquela mesma sensação, os pacientes eram induzidos a acessar o que Perls denomina de gestalts para evocar memórias profundas do inconsciente. As gestalts funcionam como caixas organizadoras da memória. Armazenam as informações por semelhanças visuais, auditivas, cinestésicas, 
linguísticas e emotivas. Ao mesmo tempo, tendem a preencher lacunas de informação quando nos deparamos com cenários fragmentados por proximidade de características (PIAGET, 2009).

Por perceber as sensações do outro através de suas manifestações físicas, sonoras e verbais, as gestalts onde armazenamos as mesmas sensações são acionadas, e eliciamos estados emotivos que nos permitem a ação de nos colocarmos no lugar do outro e de sentir como o outro. É esse processamento que nos induz a "agir por empatia" (EKMAN, 2011).

Dentro desta premissa, Damásio (2012) aponta que o sentimento (o processo de viver uma emoção) não é uma qualidade mental ilusória associada a um objeto, mas sim uma percepção direta de uma paisagem específica: a paisagem do corpo do outro, acrescentando que "os sentimentos, juntamente com as emoções que os originam, não são um luxo. Servem de guias internos e ajudam-nos a comunicar aos outros sinais que também os podem guiar" (DAMÁSIO, 2012, p. 19).

Quando vamos ao cinema, por exemplo, somos induzidos a vivenciar as emoções dos personagens por este mecanismo. Um bom filme parece ser representado por aquele que melhor consegue ativar nossa empatia. O ator que "se consagra" é aquele que expressa suas emoções de tal forma que nosso emocional adere facilmente às suas representações, e nos associamos à vivência do personagem encenado. E então choramos, sorrimos, odiamos, nos aterrorizamos e amamos em frente às telas e aos palcos. A parte consciente da mente sabe que tudo é um jogo de representações, mas, para a mente inconsciente, as emoções, as representações e os traumas são vivências reais que vão se armazenar nas gestalts que constituem o mapa cognitivo do sujeito.

Isto explica porque quando uma criança assiste a um filme de terror se paralisa frente à necessidade de sair da cama para ir ao banheiro. Significa que ela está associada, ou seja, sua mente a colocou no lugar da personagem do enredo fílmico, e ela fica à mercê do domínio de forças inconscientes e com as quais não pode lutar. É preferível fazer xixi na cama e enfrentar um possível castigo dos pais do que "encarar a morte" que se esconde no caminho até o vaso sanitário. Realidade e ficção se misturam nas gestalts, e tudo passa a ser questão de uma escolha inconsciente entre o castigo e a morte.

Roman Krznaric (2015) passou mais de doze anos estudando a capacidade empática do ser humano, e suas análises o fizeram questionar ideias de pensadores influentes e consagrados como Thomas Hobbes e Sigmund Freud, que definiam nossa espécie como essencialmente egoísta e voltada a fins individualistas. Tal descrição parece ter se tornado uma concepção dominante na cultura ocidental. De acordo com o autor, neurocientistas identificaram no cérebro humano um conjunto de circuitos de empatia com dez seções que, se danificado, pode restringir nossa capacidade de compreender o que outras pessoas estão sentindo.

\footnotetext{
Biólogos evolucionistas mostraram que somos animais sociais que evoluímos naturalmente para ser empáticos e cooperativos, como nossos primos primatas. E psicólogos revelaram que até mesmo crianças de três anos são capazes de sair de si mesmas e ver a partir das perspectivas de outras pessoas. É evidente então que temos em nossa natureza um lado empático, tão forte quanto nossos impulsos internos egoístas (KRZNARIC, 2015, p.13-14).
}

Se a empatia ocorre por processos associativos de sentimentos e emoções, a quebra ou ausência dela ocorre em processos dissociativos. Ao mesmo tempo em que defende nossa natureza empática, Krznaric (2015) versa sobre como esta propriedade inata tem sido atacada pela cultura ocidental, gerando o que chama de "déficit de empatia". Um estudo feito pela Universidade de Michigan constatou um declínio nos níveis de empatia dos jovens americanos a partir de 1980 e que estaria se acentuando até os dias atuais. Outra pesquisa realizada na Universidade da Califórnia teria mostrado que quanto 
mais rica uma pessoa é, menos empática ela tende a ser, o que explicaria os crescentes abismos sociais entre ricos e pobres nos países do terceiro mundo (KRZNARIC, 2015).

As causas para este déficit estariam relacionadas a uma "epidemia de narcisismo" alimentada pelo estilo de vida cada vez mais individualista da sociedade capitalista, fomentado pela urbanização que fragmenta comunidades e pelo distanciamento provocado pelos meios de interação de que dispomos neste sistema. A superexposição a construtos simbólicos midiatizados contribui para o que Krznaric (2015) denomina de "fadiga da compaixão" ou "fadiga da empatia", onde é permitido à maior parte de nós ter conhecimento das atrocidades e do sofrimento, e, no entanto, não agir. Isto se deve ao poder do discurso de não apenas informar, mas também eliciar certas emoções em detrimento de outras de acordo com as intenções de seu enunciador, que é o que veremos a seguir.

\section{O PAPEL DOS DISCURSOS NOS ACIONAMENTOS EMPÁTICOS}

Steven Pinker (2002) lembra que foram grandes florescimentos empáticos coletivos que proporcionaram a revolução humanitária da Europa no Século XVIII, que originaram os movimentos abolicionistas, a defesa do fim das torturas no sistema judiciário e o crescente interesse pelos direitos das crianças e dos trabalhadores. Pinker estudou como os processos empáticos são eliciados pela linguagem, e concluiu, tal qual Chomsky (2005), que a linguagem é uma aptidão inata. Trata-se de uma capacidade instintiva de designarmos sons, articularmos fonemas que formam palavras e escolher símbolos para representar nossos pensamentos, sentimentos e emoções, de forma a fazer com que o outro nos compreenda e, de forma empática, estabeleça uma interação social.

A linguagem nos permite aderir, por empatia, não somente ao que está no presente, diante dos nossos olhos, mas também ao que está distante, ao que aconteceu no passado e ao que ainda pode acontecer no futuro. Ela estabelece uma relação temporal que vai servir de conexão entre a parte consciente e a parte inconsciente da mente para formular mensagens que nos permitam experimentar as emoções e sensações do outro, de forma que gestalts sejam acionadas e o processo de entendimento ocorra.

Em uma interface com as teorias da comunicação, é esta lógica do acionamento da empatia por meio de gestalts, seja por sentimentos assistidos/descritos (acionados pelo "ser e estar presente" do corpo físico) ou recordados/representados (acionados pela codificação de situações passadas, futuras ou distantes), que estabelecemos uma padronização de vivências emocionais que vão gerar o cenário do senso comum, um campo de percepção compartilhado que se tornará matriz de eliciadores emocionais e sensoriais, como mostra a Figura 4.

Ao discorrer sobre a necessidade da alteridade do ser humano, de ser validado e reconhecido pelo outro, Mafesoli (2009) atribui à dinâmica do espelho a função de promover um "vibrar em conjunto" que alimenta a psique com a sensação de "estar vivo". Ele percebeu que o espelhamento daquilo que o outro demonstra ser é uma maneira instintiva de reconhecimento. Nas crianças a dinâmica de espelhar os adultos é a primeira forma de aprendizagem. Imitam seus formadores de crenças nos gestos, nas falas e, com o passar do tempo, no sentir e no reagir (PINKER, 2002).

As manifestações físicas do sujeito ao sentir emoções é um elemento indispensável no processo empático instintivo. Ekman (2011) percebeu isto ao identificar que as expressões faciais que demonstram as emoções são inatas, e apenas algumas variações são aprendidas. Ao perceber a emoção no outro, os autoavaliadores emocionais do sujeito percorrem um "banco de dados" armazenado no inconsciente que identifica, a partir dele, o que as expressões do outro querem dizer. 
Figura 4 - $O$ acionamento da Empatia por associação

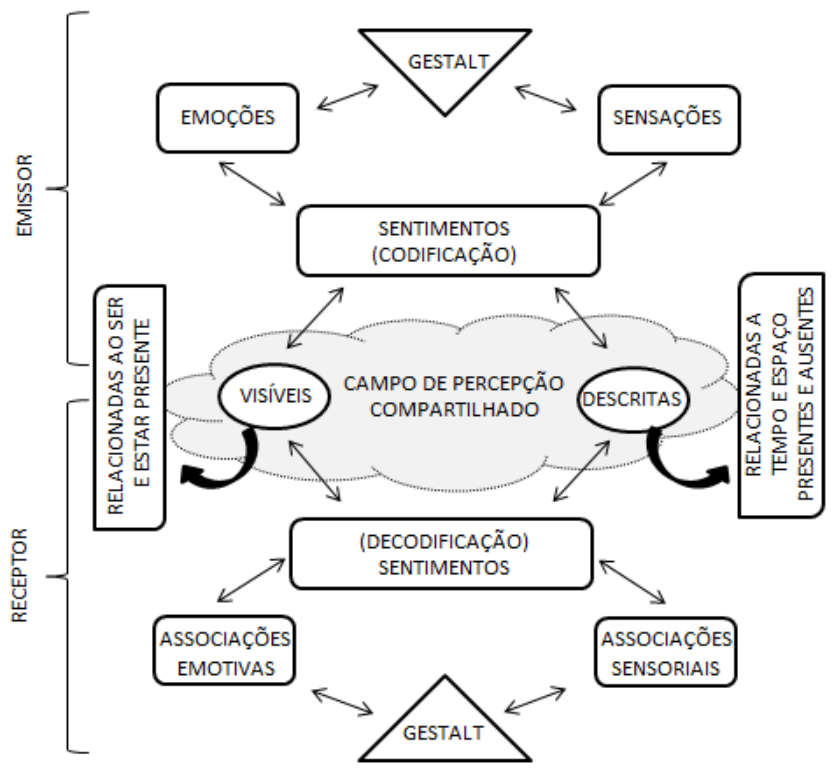

Fonte: Antunes Junior (2016)

A capacidade de se emocionar junto ao outro de maneira mediada, seja por um filme ou um jornal, está relacionada a uma propriedade da mente capaz de converter o código mediado, seja ele escrito, falado ou visualizado, em imagens, sensações, cheiros, sons e sabores que, inevitavelmente, estarão carregadas de gatilhos emocionais (EKMAN, 2011).

É como se nosso cérebro construísse um rosto matriz a partir dos elementos que recebe pelos códigos. Primeiro, ele cria imagens mentais a partir de um código disponível. Os autoavaliadores percebem estas imagens e, ao colocá-las em confronto com gatilhos/âncoras, disparam emoções e sensações que vão eliciar memórias gestálticas. Estas memórias vão criar o rosto matriz, pelo qual o sujeito estabelece empatia. A cada elemento novo, mais detalhes este rosto recebe e, quanto mais detalhes, maior o potencial empático dos códigos mediados. E rosto matriz, ou "rosto empático" (ANTUNES JUNIOR, 2016) não é necessariamente um rosto com olhos, nariz e boca, mas uma base referencial que transmite ao receptor do código emoções a partir da composição dos elementos que lhe eliciam estados internos emotivos, conforme mostra a Figura 5.

Figura 5 - A formação do rosto empático

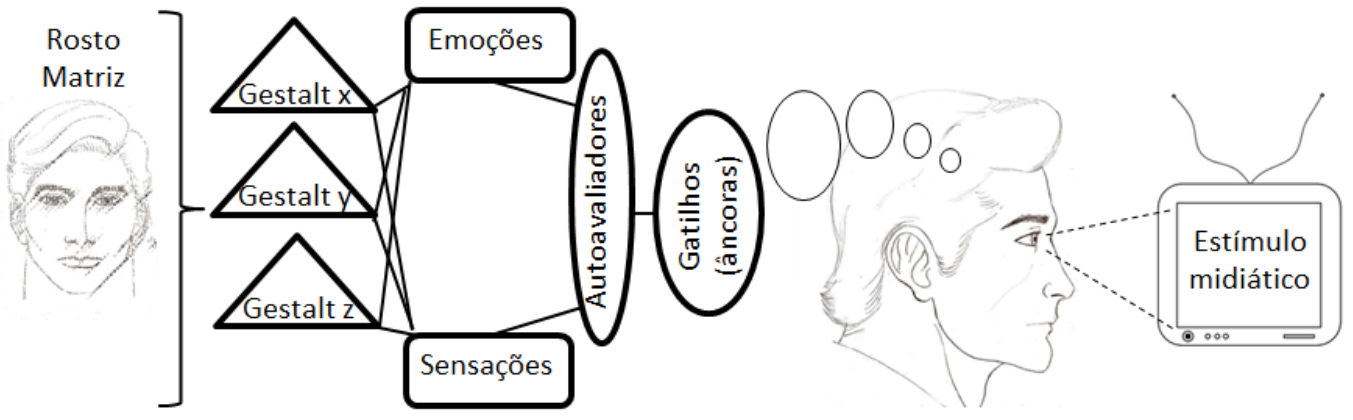

Fonte: Antunes Junior (2016) 
Krznaric (2015) lembra que a capacidade de se colocar no lugar do outro é aumentada quando somos capazes de identificar pontos de experiência comum que nos sensibilizam com suas paisagens mentais.

O inatismo desta propriedade fica ainda mais latente quando é percebido também nos animais. Monty Roberts, famoso domador de cavalos dos Estados Unidos, desenvolveu uma técnica a qual batizou de join $u p^{10}$, que consiste em detectar os estados emocionais dos cavalos e estabelecer uma comunicação empática a partir de códigos físicos corporais. Roberts descobriu, por exemplo, que quando levantava as mãos com os dedos abertos na altura dos ombros, os cavalos demonstravam sinais físicos de medo. Talvez em analogia aos gestos das garras feitos por predadores naturais destes animais. Por mecanismos de tentativa e erro, Roberts desenvolveu toda uma linguagem que o permite montar em um potro selvagem em questão de minutos, algo que seu pai demorava de seis a oito semanas para realizar pelos métodos tradicionais (ROBERTS, 2001).

Podemos assumir, portanto, que o processo empático é o primeiro estágio do ato comunicativo, que está ligado à capacidade de reconhecer estados emotivos no outro a partir de referências universais (inatas) e aprendidas (condicionadas). A capacidade de manifestar e de perceber o sentir através da linguagem, seja ela física, falada ou escrita, vai interferir na organização da mente, tanto em seus processamentos conscientes quanto inconscientes, afetando a cognição, o aprendizado e a formação das crenças e diretrizes que vão gerar comportamentos.

Quando estamos em processo empático, há um reconhecimento do outro em nós mesmos, e um reconhecimento do "nós" no outro. Assim, é como se duas mentes entrassem em concordância sobre o que as fazem sofrer, bem como o que lhes causa angústia, bem-estar, prazer e tantas outras sensações, ou seja, um compartilhamento de pensamentos e memórias coletivos e discursivos, sobre os quais são construídos e compartilhados saberes de conhecimento e de crença sobre o mundo. Basicamente, por entrarmos nesse processo empático, nos tornamos mais suscetíveis ao que o outro sugere, aceitando suas verdades como possíveis, e agregando estas novas diretrizes à nossa rede de crenças. É deste processo que a propaganda e o cinema fazem uso para venderem produtos, serviços e ideias, por exemplo (CHARAUDEAU, 2004).

Ao mesmo tempo em que o processo empático é desencadeado pelos autoavaliadores que reconhecem as emoções do outro e acionam emoções similares no observador, a interrupção deste processo, ou a ausência de empatia, se dá quando o "rosto empático" é impedido de emergir em nossa psique. As generalizações, omissões e distorções impostas pela linguagem, por exemplo, geralmente são elementos de ocultação ou distorção de gatilhos emocionais. Dessaforma, pode ocorrer um acionamento emocional ou sensorial distorcido, ou pode nem ocorrer, de acordo com o contrato comunicativo que é estabelecido. Vale lembrar que, segundo Charaudeau (2016, p. 56), "a noção de contrato pressupõe que os indivíduos pertencentes a um mesmo corpo de práticas sociais estejam suscetíveis de chegar a um acordo sobre as representações linguageiras dessas práticas sociais”, ou seja, a construção lingüística se dá na expectativa de uma contrapartida de conivência do destinatário com o enunciador.

A crítica de Krznaric (2015) aos meios de comunicação e sua enxurrada de informações se fundamenta diante deste aspecto. A presença massiva de violência e sofrimento nos mass media podem anestesiar o espectador por dificultar ou encobrir o surgimento do "rosto empático". Ao massificar construtos sobre uma multidão sem rosto, números sem rosto, ou qualquer outra generalização que retire as individualidades de um grupo, os meios o tornam uma massa homogênea e disforme. Diante de tal

${ }^{10}$ Juntar-se, na tradução livre. 
contrato os mecanismos da empatia não conseguem identificar sinais emocionais que ativem o "rosto empático" interno.

Para explicar como estas dinâmicas de acionamento ou inibição da empatia se desenrolam a partir do consumo de construtos simbólicos nos meios de comunicação, um evento midiático ocorrido em agosto de 2015 nos serve de exemplo. Um caminhão carregado com 110 porcos tombou próximo a um dos pedágios do Rodoanel Metropolitano de São Paulo (Figura 6). O acidente começou a ganhar dimensão quando vídeos da "carga", presa na carreta tombada, começaram a aparecer nas redes sociais ${ }^{11}$. Imagens e sons de animais em claras manifestações de sofrimento, dor e angústia acionaram gatilhos emocionais que permitiram a formação de um o "rosto empático" no imaginário coletivo.

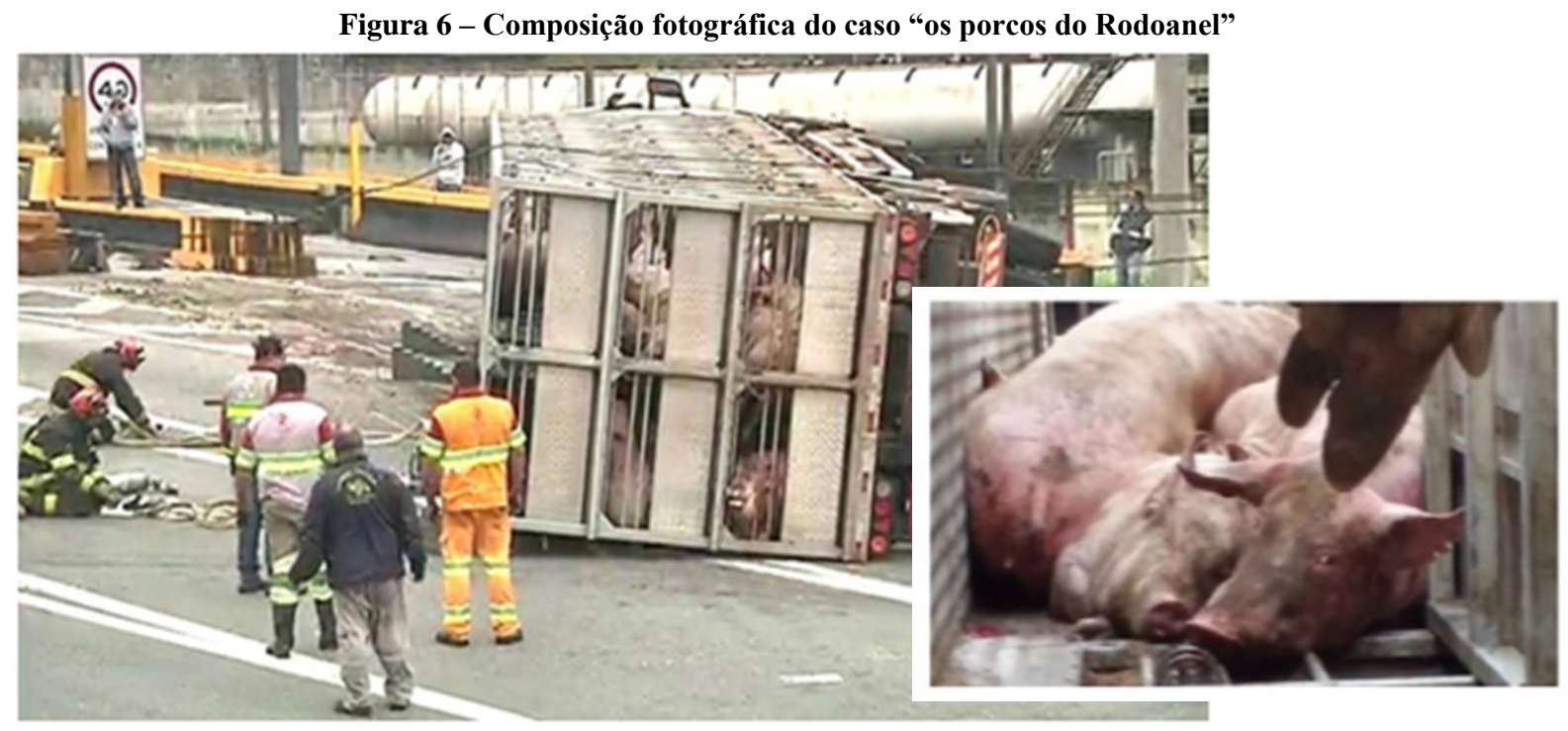

Fonte: Foto maior: Band ${ }^{12}$. Foto menor: Blog O Holocausto Animal ${ }^{13}$.

As primeiras tentativas de resgate foram classificadas como "desastrosas" pelos jornalistas que acompanharam a ação. Ativistas pelos direitos dos animais foram até o local para ajudar no resgate e, de seus celulares, enviavam imagens ${ }^{14}$ que agregavam cada vez mais detalhes ao rosto empático gerado pelo sofrimento dos porcos. O olhar de pavor, em meio a gritos desesperados que lembram "choro de criança" foram elementos de humanização das expressões faciais dos porcos, que gradualmente perderam a alcunha de "carga" frente ao processo empático desperto. Há um deslocamento da memória das situações de comunicação (CHARAUDEAU, 2014), quando os porcos deixam de ser as mercadorias vendidas nos supermercados para se tornarem serem sencientes em uma evidente situação de sofrimento. A morte antes aceita perante o contrato comunicativo da propaganda, agora passa a ser rejeitada frente ao rosto empático construído pela cobertura jornalística do acidente.

Depois de todo o drama vivido, a ideia de que aqueles seres portadores das mesmas emoções e sentimentos que o "eu" coletivo seguissem seu destino para se tornar comida passou a ser rejeitada. A comoção foi tamanha que uma ação online ${ }^{15}$ arrecadou cerca de $\mathrm{R} \$ 300$ mil para que os sobreviventes

\footnotetext{
${ }^{11}$ Cobertura feita pela Rede Globo. Disponível em: <https://globoplay.globo.com/v/4419689/>. Acesso em: 01 jul. 2016.

12 Disponível em: <http://noticias.band.uol.com.br/transito-sp/noticia/100000768068/acesso-do-rodoanel-sentido-dutra-estafechado-.html>. Acesso em: 01 jul. 2016.

${ }^{13}$ Disponível em: <https://oholocaustoanimal.wordpress.com/2015/08/26/eu-desabei-diz-ativista-que-participou-do-resgatedo-acidente-no-rodoanel/acidente-rodoanel-porcos-grande-sao-paulo-miniatura/>. Acesso em 01 jul. 2016.

${ }^{14}$ Disponível em <https://www.youtube.com/watch?v=sN5OVrXpSOI>. Acesso em 01/07/2016.

${ }^{15}$ Disponível em: <https://www.vakinha.com.br/porcos-do-rodoanel>. Acesso em: 01 jul. 2016.
} 
se livrassem do fatídico destino do abatedouro e ganhassem uma nova chance de vida em um santuário para animais.

O caso dos porcos do Rodoanel merece especial atenção não só por demonstrar o poder empático das emoções quando estas são manifestadas e identificadas por nossos autoavaliadores, mas também por tornar evidente quão apáticos podemos nos tornar quando estes processos emotivos são generalizados, ocultados ou distorcidos.

Dessa forma, apresenta-se o fato de que não é possível estabelecer empatia se as emoções dos animais estão afastadas de nossas percepções. Ao mesmo tempo, criar personagens que representem estes animais, com traços infantis e expressões faciais de alegria e felicidade, para estampar peças publicitárias e embalagens de produtos, é uma estratégia que coloca um rosto empático distorcido no lugar daquele que provavelmente emergiria diante do sofrimento ante o confinamento e o abate.

Ocultar ou distorcer as emoções dos animais tornaram-se estratégias recorrentes da propaganda desta indústria. Geralmente, as campanhas publicitárias são acompanhadas de personagens sorridentes e convidativos, como se eles estivessem felizes ou satisfeitos por serem consumidos ou explorados. Recorre-se aqui a uma memória das formas de signos (CHARAUDEAU, 2004) que cria uma leitura semiológica cujo julgamento ético torna-se favorável ao consumo destes animais. Uma rápida busca na internet sobre grandes marcas de carne, leite e derivados evidencia que os indutores empáticos inatos do ser humano são uma preocupação da indústria que explora animais, como mostram algumas logomarcas reunidas na Figura 7.

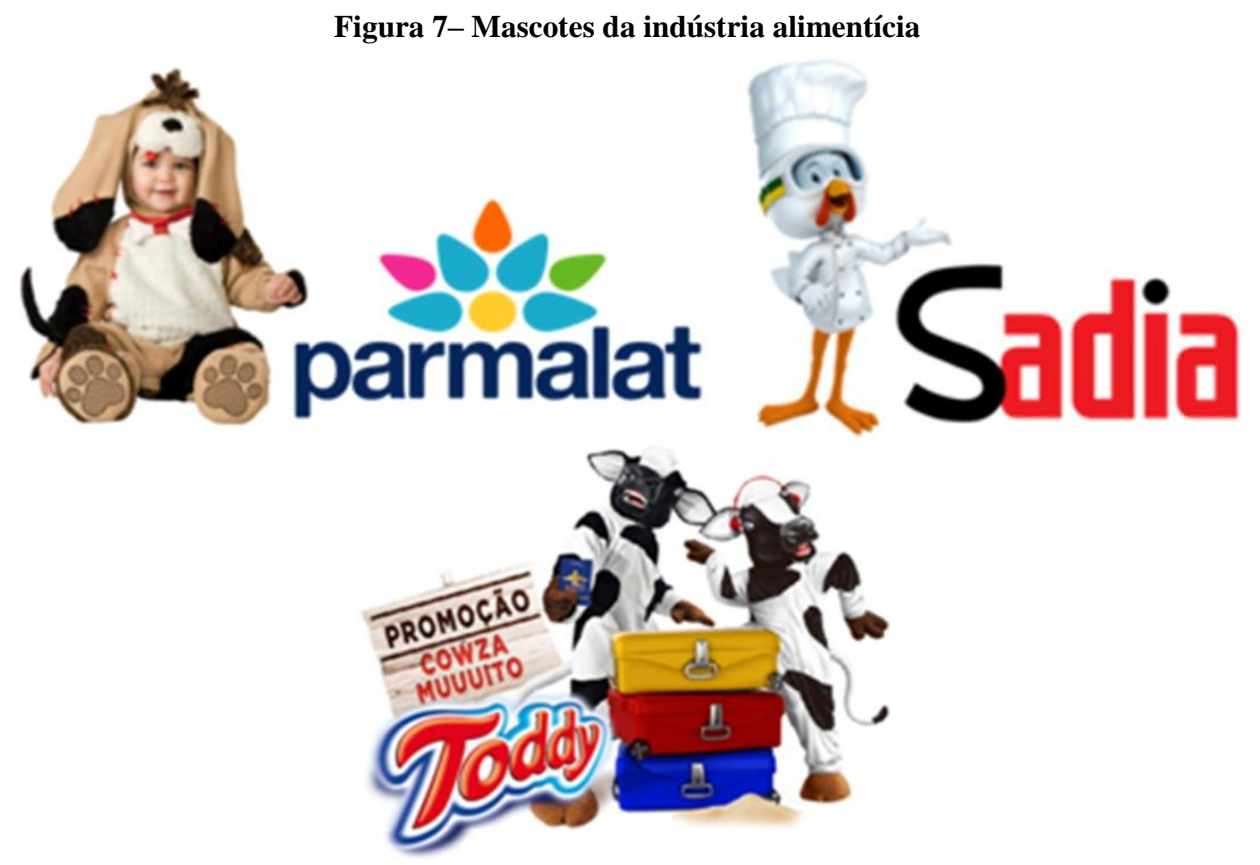

Fonte: Painel elaborado pelos autores com logomarcas retiradas da internet

Em alguns casos, o rosto do animal é ocultado. Olhos, nariz e boca desaparecem em silhuetas que entregam a espécie, mas não o indivíduo, de forma que não seja possível identificar emoções ou sensações, como mostram as logomarcas de empresas produtoras de carne da Figura 8. 
Figura 8 - Logotipos de empresas produtoras de carne

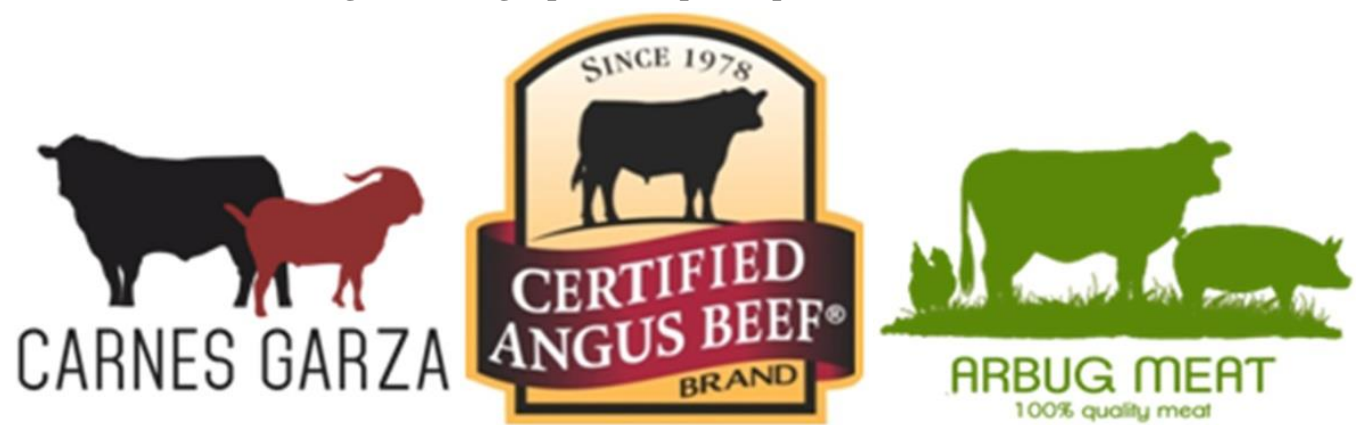

Fonte: Painel elaborado pelos autores com logomarcas retiradas da internet

Em sua conceituação sobre estratégias de discurso, Charaudeau (2016, p. 56) pressupõe que o sujeito comunicante "concebe, organiza e encena suas intenções de forma a produzir determinados efeitos - de persuasão ou de sedução - sobre o sujeito interpretante, para levá-lo a se identificar - de modo consciente ou não - como o sujeito destinatário ideal".

Reconhecer, portanto, os dispositivos que acionam nossos operadores emocionais e nossa natureza empática, sejam eles linguísticos ou simbólicos, é o primeiro passo para adquirirmos o que os neurocientistas chamam de inteligência emocional. É trazer à luz da consciência os indutores que controlam nossos estados internos e, a partir desta conscientização, modificá-los ou até mesmo desativálos (DAMÁSIO, 2000). A seguir propomos um entendimento acerca das estratégias enunciativodiscursivas da publicidade que faz uso destes operadores emocionais para distorcer ou anular os processos empáticos.

\section{ATITUDES ENUNCIATIVO-DISCURSIVAS PARA ANULAR OU DISTORCER A EMPATIA}

A percepção de que somos suscetíveis a mecanismos empáticos inatos leva os enunciadores da indústria da carne a adotarem estratégias discursivas que nos afastem das similitudes com os animais. Para identificar o jogo enunciativo que busca objetificar seres sencientes ou até mesmo normatizaro consumo e a exploração de animais em nome do prazer e do bem-estar, recorreremos ao que Charaudeau (2004) conceituou como sendo as visadas.

Sabendo que, para ter sucesso, a propaganda carnista $^{16}$ (FELIPE, 2014; JOY, 2015) necessita ocultar ou distorcer o rosto empático, os enunciadores recorrem aatitudes enunciativas de base que constituem os atos comunicativos reagrupados em nome de uma orientação pragmática. Charaudeau (2004) sugere que os tipos de visadas são definidos por um duplo critério: a intenção pragmática do $E U$ em relação com a posição que ele ocupacomo enunciador na relação de força que o liga ao $T U$; e a posição que da mesma forma $T U$ deve ocupar no jogo enunciativo. Charaudeau descreve as seis principais visadas que determinam a expectativa (enjeu) do ato de linguagem do sujeito falante e, por conseguinte, da própria troca linguageira.

\footnotetext{
${ }^{16}$ O termo "carnismo" é usado para descrever a ideologia que defende o consumo de carne e seus derivados. Foi concebido pela psicóloga social Melanie Joy e popularizado pelo livro de sua autoria Por que amamos cachorros, comemos porcos e vestimos vacas (2015). O livro se propõe a analisar um paradoxo aparente no comportamento generalizado das pessoas em relação aos animais - elas demonstram compaixão para com algumas espécies enquanto se alimentam de outras. O fenômeno ficou conhecido como o "paradoxo da carne", no qual pessoas que se opõem aos maus tratos aos animais se envolvem em comportamentos que resultam justamente no oposto disto. Os psicólogos sugerem que o desconforto revelado por este conflito é anulado pelos "quatro Ns", a percepção que comer carne é "natural, necessário, normal e bom" (JOY, 2015).
} 
Na visada de "prescrição", o $E U$ (ou o comunicante) quer "mandar fazer" (faire faire), e ele tem autoridade de poder sancionar; enquanto o $T U$ (ou o receptor) se encontra, então, em posição de "dever fazer". Na visada de "solicitação", o EU quer "saber", e ele está, então, em posição de inferioridade de saber diante do $T U$ mas legitimado em sua demanda, enquanto o $T U$ está em posição de "dever responder" à solicitação. Na visada de "incitação", o EU quer "mandar fazer" (faire faire), mas não estando em posição de autoridade, não pode senão incitar a fazer; ele deve, então, "fazer acreditar" (por persuasão ou sedução) ao $T U$ que ele será o beneficiário de seu próprio ato; enquanto o $T U$ está, desse modo, em posição de "dever acreditar" que se ele age, é para o seu bem. Na visada de "informação", o $E U$ quer "fazer saber", e ele está legitimado em sua posição de saber, enquanto $T U$ se encontra na posição de "dever saber" alguma coisa sobre a existência dos fatos, ou sobre o porquê ou o como de seu surgimento. Na visada de "instrução", o $E U$ quer "fazer saber-fazer", e ele se encontra ao mesmo tempo em posição de autoridade de saber e de legitimação para transmitir o saber, enquanto $T U$ está em posição de "dever saber fazer" segundo um modelo (ou modo de emprego) que é proposto por $E U$. Por último, a visada de "demonstração" sugere que o $E U$ quer "estabelecer a verdade e mostrar as provas" segundo uma certa posição de autoridade de saber (cientista, especialista, expert), enquanto o $T U$ está em posição de ter que receber e "ter que avaliar" uma verdade e, então, ter a capacidade de fazê-lo (CHARAUDEAU, 2004, p. 5).

Cada situação de comunicação seleciona, para definir sua finalidade, uma ou várias visadas, mas Charaudeau (2004) lembra que as visadas não correspondem ao todo da situação de comunicação. Elas vão se combinar a outros elementos, como a identidade dos participantes do jogo enunciativo; o propósito e a estruturação temática do construto simbólico; e as circunstâncias das condições materiais da comunicação.A seguir, analisaremos de que forma estas atitudes enunciativas são adotadas como estratégias discursivas para anulação da empatia em peças publicitárias carnistas.

\section{OMISSÕES E DISTORÇÕES EM ANÁLISE}

Como a intenção deste artigo é identificar estratégias discursivas de anulação da empatia em campanhas publicitárias de marcas de carnes brasileiras, foram selecionadas três peças estáticas de três empresas líderes no mercado de carnes e embutidos que renovaram suas campanhas entre 2013 e 2014, durante uma forte crise enfrentada pelo setor de aves e de carne, cujo ápice foi em $2015^{17}$.Tal crise resultou no fechamento de 26 frigoríficos no Brasil em 2015.

A primeira peça a ser analisada é da marca Friboi, vinculada à campanha "Peça Friboi: carne confiável tem nome", estrelada pelo ator Tony Ramos e veiculada em 2013. A segunda é da marca Seara, que integra a campanha "A qualidade vai te surpreender", estrelada pela jornalista Fátima Bernardes e disseminada nos meios de comunicação em 2014. Já a terceira peça é da marca Sadia, estrelada pelo mascote da empresa Lequetreque, o simpático franguinho de capacete criado em 1971 pelo publicitário Francesc Petit ${ }^{18}$, ligada à campanha "Onde tem S de Sadia, não tem hormônios", veiculada também em 2014.

\footnotetext{
${ }^{17}$ Entre 2011 e 2015 o setor de bovinos reduziu sua produção anual em 2,5 milhões de cabeças de gado, segundo dados do Ministério da Agricultura. Disponível em: <http://g1.globo.com/jornal-da-globo/noticia/2015/06/crise-economica-no-paischega-aos-frigorificos-e-falta-ate-carne-de-boi.html>. Acesso em: 20 jun. 2017.

${ }^{18}$ A origem é descrita no blog "Mundo das Marcas", disponível em: <http://mundodasmarcas.blogspot.

com.br/2006/05/sadia-lequetreque.html>. Acesso em: 20 jun. 2017.
} 
Pretende-se, com estas análises, fazer emergir os possíveis interpretativos (CHARAUDEAU, 2016) que surgem no ponto de encontro dos processos de produção e interpretação dos discursos empregados pela indústria da carne no Brasil nos últimos anos, com o intuito de identificar a presença de visadas e estratégias para anulação da empatia como elemento favorável ao consumo.

\section{1 A CONFIANÇA DO ATOR CONSAGRADO}

Tony Ramos é um ator consagrado da televisão brasileira, onde atua desde 1964 e se popularizou por papéis marcantes nas telenovelas. Geralmente associado a personagens arquetípicos do herói ou do sábio (JUNG, 1991, 2011), já recebeu diversos prêmios por suas performances, agregando sua imagem a valores como profissionalismo, seriedade e confiança, tornando-o assim um ícone de confiança.

Ao utilizar o ator em sua campanha, a Friboi evoca uma memória das formas de signos e convida o $T U$ destinatário (TUd) a compartilhar não apenas de um produto, mas de uma sensação de "confiança". O rosto empático emerge pelo ator familiar, e não pelo animal que foi sacrificado. O sorriso no rosto é sereno e tranqüilizador. O olhar direto para o espectador convida a uma normalidade de situação, sem qualquer conflito moral ou ético que possa estar envolvido no consumo da carne. O deslocamento aqui não é em relação a se é apropriado ou não comer carne, mas sim à escolha de qual carne comer. Evidencia a ideologia do carnismo como ethos discursivo (MAIGUENEAU, 2015).

O slogan da campanha, por sua vez, objetifica o animal morto como sendo um mero produto. Evoca as visadas de prescrição (CHARAUDEAU, 2004), por "mandar fazer" o $T U$ pedir Friboi, ao mesmo tempo que recorre à incitação, pois recorre a uma identidade específica, neste caso a de Tony Ramos, para seduzir o TU a ponto de fazê-lo acreditar que "carne de confiança tem nome" (Figura 9).

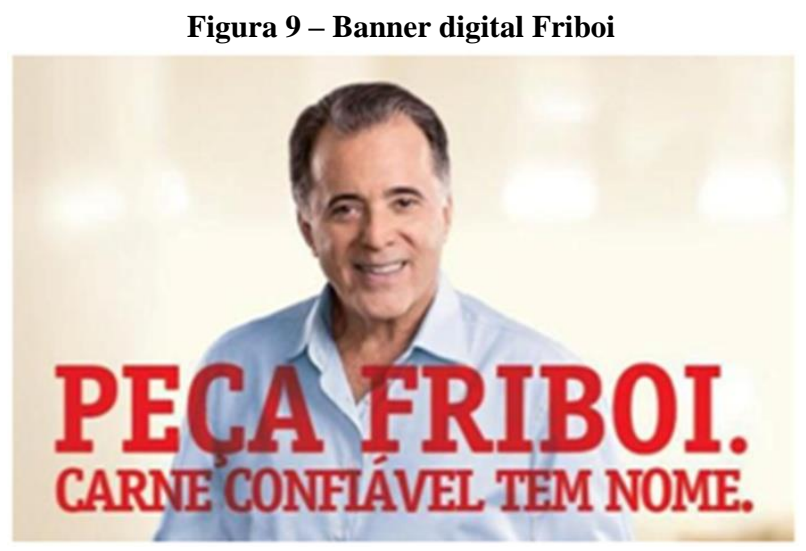

Fonte: Portal Inteligemcia ${ }^{19}$

Os possíveis interpretativos que se cristalizam como resultado de tal peça deixa alguns explícitos e implícitos que corroboram a ideia de anulação ou distorção de mecanismos empáticos (KRZNARIC, 2015; ANTUNES JUNIOR, 2016) para uma potencialização do consumo. Como mensagem explícita, o $E U$ enunciador (EUe) direciona o $T U$ destinatário (TUd) a pedir carne Friboi, pois é uma carne confiável. Nos implícitos, o $E U$ enunciador está alertando o $T U$ destinatário que existem carnes que não são confiáveis. Ao mesmo tempo, induz ao pensamento de que carne é um objeto de consumo para o qual é possível atribuir valores que atestam sua qualidade enquanto produto, mas não enquanto parte de um ser consciente ao qual se agregam valores humanos.

${ }^{19}$ Disponível em: <http://www.inteligemcia.com.br/campanha-friboi-recebe-premio-marketing-best-2013/>. Acesso em: 10 dez. 2016. 
Ainda é possível perceber nos implícitos que "se a carne Friboi é de confiança, logo, ao consumila, só é possível obter benefícios", e que "se o Tony Ramos, a quem se acompanha há mais de 50 anos na televisão, diz com um sorriso no rosto que se deve pedir Friboi, isto também só pode ser uma coisa boa”. Estas mesmas estratégias e visadas foram utilizadas pela marca Seara, como veremos a seguir.

\subsection{A CREDIBILIDADE QUE ATESTA QUALIDADE}

A estratégia discursiva da marca de presuntos e embutidos Seara segue uma linha semelhante à Friboi. Mas ao invés de um ator conhecido dos brasileiros, a marca recorre à imagem da premiada jornalista Fátima Bernardes, que durante 14 anos foi apresentadora do Jornal Nacional, da TV Globo, e atualmente comanda um programa diário de entrevistas, variedades e curiosidades chamado Encontro com Fátima Bernardes. Além de jornalista, a apresentadora por muito tempo ocupou o imaginário coletivo brasileiro, ao lado do ex-marido, o também jornalista Willian Bonner, como ícone de valores do casamento e da família feliz.

O sorriso leve, característico da apresentadora, evoca a memória discursiva que a tornou "musa da torcida brasileira" na Copa do Mundo de Futebol de 2010 e de 2014, quando trazia notícias da delegação brasileira. O carisma e a simpatia de Fátima são usados para normalizar o consumo dos embutidos da marca, ao mesmo tempo em que busca atribuir qualidade aos produtos.

Também a exemplo da estratégia discursiva da Friboi, a campanha da Seara recorre às visadas de prescrição (CHARAUDEAU, 2004), ao "mandar" o TUd experimentar os produtos ofertados, e também à incitação, ao garantir que o $T U$ "irá se surpreender" de forma positiva se acatar à visada proposta. $\mathrm{O}$ rosto empático (ANTUNES JUNIOR, 2016) a emergir de tal construto induz o $T U$ a estabelecer laços com Fátima, aqui no papel da mãe de família, que sugere também uma normalização do consumo, sem qualquer preocupação ética ou moral em relação a origem dos produtos. Os animais são ocultados do mise en scène, onde só existe uma Fátima feliz e produtos com uma suposta qualidade (Figura 10).

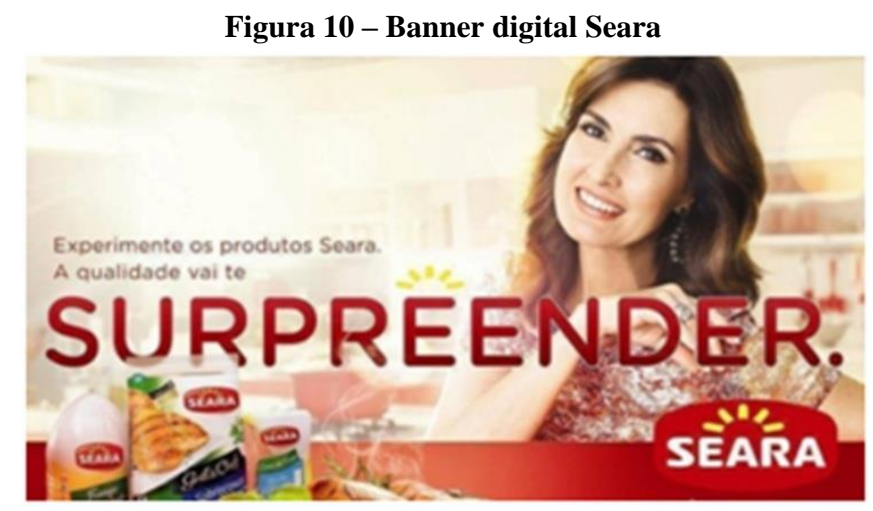

Fonte: Grandes Nomes da Propaganda ${ }^{20}$

Os elementos semânticos, linguageiros e formais dos possíveis interpretativos da peça convidam explicitamente o TUda experimentar e se surpreender positivamente com os produtos Seara, caracterizando uma estratégia discursiva enunciativa que estabelece uma relação de influência com esseTU. Desta dinâmica emergem implícitos que vão orbitar a mise en scène (CHARAUDEAU, 2016) proposto pela propaganda, que sugerem que "produtos Seara são diferentes dos demais", que "se a Fátima Bernardes fica feliz ao consumir Seara, isto só pode ser positivo", e que "aos produtos Seara só

${ }^{20}$ Disponível em: <http://grandesnomesdapropaganda.com.br/anunciantes/fatima-bernardes-estreia-como-garota-propagandada-seara/>. Acesso em: 10 dez. 2016. 
podem ser atribuídos valores enquanto coisas, e não enquanto resultado de um processo resultante da manipulação de seres vivos".

Tanto a estratégia da Seara quanto da Friboi buscam anular os processos empáticos omitindo a origem animal dos produtos e eliciando emoções positivas para o consumo. A terceira peça a ser analisada segue uma proposta um pouco distinta, pois ao invés da omissão, apela à distorção para alcançar o mesmo resultado, como veremos a seguir.

\subsection{A FELICIDADE QUE INOCENTA O CONSUMO}

A terceira peça a ser analisada promove um deslocamento discursivo não no sentido de ocultar, mas sim distorcer o rosto empático a ser eliciado. Estrelada pelo mascote Lequetrefe, o franguinho da Sadia, a campanha "Sem Hormônios" recorre ao imaginário infantil para estabelecer uma mise en scène que evoque alegria e inocência. Nas propagandas da Sadia em geral, a origem do produto não fica ocultada no contrato enunciativo de comunicação (CHARAUDEAU, 2016), visto que os produtos têm origem na produção de frangos e outras aves. No entanto, a estratégia discursiva recorrente da marca atribui um rosto ao personagem cujas emoções não condizem com a de um ser consciente perante a morte. A expressão de Lequetrefe é sempre alegre, convidativa, como se dissesse ao TUd que ele é feliz em servir de alimento, uma espécie de "suicida feliz".

$\mathrm{Na}$ campanha específica em questão, Lequetrefe veste um jaleco branco comum em frigoríficos e ambientes onde se exige higienização. Ele segura uma caneta e uma planilha onde se lê "sem hormônios", acompanhado de "v" estilizado, símbolo comum para assinalar itens de checagem. A organização do discurso (CHARAUDEAU, 2016) está calcada em uma característica bastante denunciada no mercado da carne de aves, que é o uso de hormônios para fazer com que os frangos cresçam mais rápido. A frase "É simples: onde tem S de Sadia, não tem hormônios nem conservantes", acompanhada do complemento "Escolha frango saudável. Escolha frango com S de Sadia", estabelece um modo de organização argumentativo, que tenta situar a marca como uma marca de confiança e qualidade em um mercado de práticas não saudáveis e antiéticas (Figura 11).

Figura 11 - Banner digital Sadia sem hormônios

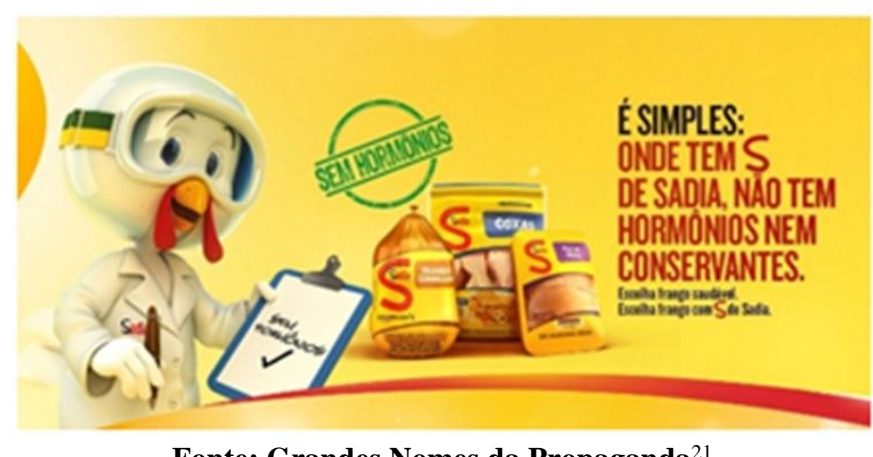

Fonte: Grandes Nomes da Propaganda ${ }^{21}$

Enquanto a mensagem explícita dá salvaguarda aos frangos da Sadia, os possíveis interpretativos implícitos sugerem um cenário de normalização do consumo, de onde algumas inferências emergem da peça, como as que induzem ao entendimento de que: 1) os frangos da Sadia, por serem saudáveis, fazem bem à saúde; 2) os frangos da Sadia são felizes e ficam felizes em nos servir de alimento; 3) existem

${ }^{21}$ Disponível em: <http://grandesnomesdapropaganda.com.br/anunciantes/fatima-bernardes-estreia-como-garota-propagandada-seara/>. Acesso em: 10 dez. 2016. 
frangos que tem hormônios e conservantes; 4) hormônios e conservantes não fazem bem à saúde. Tais implícitos ficaram tão evidentes que, segundo notícia publicada em $O G_{l o b o} 22$ no dia 17 de fevereiro de 2014, gerou um mal-estar no setor, a ponto de levar a União Brasileira de Avicultura (UBABEF) a se manifestar em nota, na qual afirma que "toda a carne de frango produzida no Brasil, com selo do Serviço de Inspeção Federal (SIF), não usa hormônios ou conservantes". Aqui o conflito ético é deslocado do "consumir ou não animais conscientes" para o "que carne devo escolher para consumir", distanciando o consumidor de qualquer manifestação empática pró animais.

\section{CONSIDERAÇÕES FINAIS}

A desumanização dos negros na escravidão, dos judeus no nazismo, das mulheres ao longo da história e a inferiorização de animais na sociedade de consumo seguem um mesmo princípio distorcivo que nos afasta da empatia. Para justificar tais atrocidades, o grupo dominante recorre a estratégias discursivas que normalizam ou naturalizam a exploração. As relações de poder que regem o sistema social se transferem para o prato.

As três peças analisadas mostram um esforço publicitário em desviar o foco para acionamento dos processos empáticos inatos. Estabelecem uma encenação enunciativa com o $T u$ carregada de variáveis argumentativas que remontam um clima familiar, quase de cumplicidade emocional, isentando de culpa qualquer ação favorável ao consumo dos produtos ofertados.

Quando não oculta a origem dos produtos, estabelece uma encenação que busca eliciar emoções aliadas ao prazer e à alegria do consumo, buscando anular qualquer pareamento emocional negativo, que remeta ao sofrimento ou exploração de animais. A mesma estratégia foi utilizada pela propaganda brasileira na primeira metade do século XX, que colocavam um brasileiro pacato e feliz como sendo o "senhor do lar", sempre recebido pela "esposa dona de casa", feliz e realizada com sua função meramente doméstica na família (Figura 12).

Figura 12 - Propaganda da Pomada Minâncora em 1930

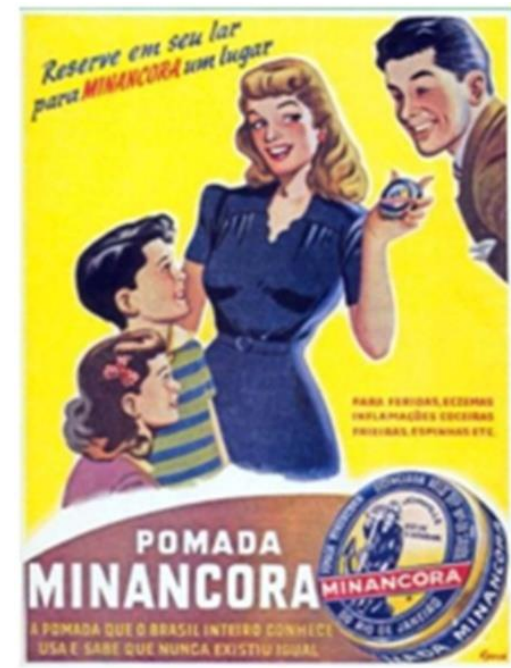

Fonte: Blog História da Publicidade ${ }^{23}$

\footnotetext{
${ }^{22}$ Disponível em: <https://oglobo.globo.com/economia/anuncio-de-frango-sem-hormonio-da-sadia-gera-mal-estar-no-setor11634054>. Acesso em: 15 dez. 2016.

${ }^{23}$ Disponível em <http://migre.me/uxKTR>. Acesso em: 20 jul. 2016.
} 
Para a ideologia de consumo operar, ela depende da desconexão empática, não só em relação aos animais, mas também em relação ao outro e ao meio. Não convém ao mercado que o consumidor perceba que o mundo é limitado, onde os recursos naturais são finitos e cada vez mais escassos. Se percebêssemos isto, o ritmo de consumo seria colocado em estado reflexivo. Tomar a decisão de não comprar e não consumir torna-se mais segura quando o ato em si é colocado em contra prova a valores fundamentais. Matar, subjugar e destruir, ao contrário do que possa parecer, não faz parte da natureza empática do ser humano. Basta ver como uma criança se comporta ante o sofrimento de qualquer ser vivo. Ela chora, sofre junto e tenta barrar a causa da angústia a qualquer custo.

Com a influência dos discursos que formam a cultura e a tradição, estas potencialidades vão sendo direcionadas. A publicidade, em seu papel normatizador, atenua as incongruências que ela mesma vende. Fabrica a ideia de que é normal sermos contraditórios, ou de que está tudo bem ante o sofrimento e a inferiorização do outro.

Krznaric (2015) relembra a história de Oscar Schindler, impetuoso homem de negócios nazista que se transformou num dos maiores salvadores de vítimas do holocausto. Schindler, no dia 08 de junho de 1942, experimentou um momento de epifania empática ao presenciar o sofrimento de judeus que estavam sendo exterminados na Cracóvia. Ali, a presença ante o sofrimento eliciou estados mais profundos que a norma criada pelo discurso nazista. Como relata Krznaric (2015), talvez esta tenha sido a primeira vez que Schindler viu os judeus como seres humanos.

O mesmo processamento empático hoje permeia o discurso de movimentos sociais que lutam pela defesa de minorias, ante a um discurso massificado que costuma criminalizar negros, pobres, mulheres, LGBTs ou qualquer ativista que se oponha às lógicas de mercado.O crescimento dos movimentos abolicionistas e pró animalistas mostram que a mise em scène proposto pela ideologia dominante tem um alcance limitado, principalmente ante a força das redes sociais. Hábitos alimentares como o vegetarianismo estrito, bem como filosofias de vida como o veganismo, que prega a libertação e a não exploração de animais para qualquer fim, mostram um crescimento vertiginoso nos últimos anos (FELIPE, 2014), sinal de que os mecanismos empáticos inatos do ser humano são capazes de resistir à manipulação publicitária quando alimentados pelo conhecimento.

\section{REFERÊNCIAS}

ANTUNES JUNIOR, F. S. A retórica do medo: uma análise neurolinguística da mídia. 2016, 309 f. Tese (Doutorado). Programa de Pós-Graduação da Faculdade dos Meios de Comunicação Social da Pontifícia Universidade Católica do Rio Grande do Sul (PPGCOM - PUCRS). Disponível em: <http://tede2.pucrs.br/tede2/handle/tede/7000?mode=full>. Acesso em: 15 abr. 2017.

CHARAUDEAU, P. Visadas discursivas, gêneros situacionais e construção textual. In: MACHADO, Ida Lucia; MELLO, Renato de. Gêneros reflexões em análise do discurso. Belo Horizonte, Nad/FaleUFMG, 2004. Disponível em: <http://www.patrick-charaudeau.com/Visadas-discursivasgeneros.html>. Acesso em: 20 jun. 2017.

. Las emociones como efectos de discurso. Revista Versión, n²6, junio 2011, La experiencia emocional y sus razones, pp.97-118, UAM, México. Disponível em:

<http://www.patrickcharaudeau.com/Lasemocionescomoefectosde.html>. Acesso em: 15 abr. 2017.

Linguagem e discurso: modos de organização. São Paulo: Contexto, 2016.

DAMÁSIO, A. O mistério da consciência: do corpo e das emoções ao conhecimento de si. São Paulo: Companhia das Letras, 2000. 312 p. 

2012. $336 \mathrm{p}$.

O erro de Descartes: emoção, razão e o cérebro humano. São Paulo: Companhia das Letras,

EKMAN, P. A linguagem das emoções. São Paulo: Lua de Papel, 2011. 288 p.

FELIPE, S. T. Acertos abolicionistas: a vez dos animais: crítica à moralidade especista. São José, SC: Ecoânima, 2014. 304 p.

JOY, M. Por que amamos cachorros, comemos porcos e vestimos vacas. São Paulo: Editora Cultrix, 2015. 200 p.

JUNG, C. G. A dinâmica do inconsciente. Petrópolis, RJ: Vozes, 1991. 534 p.

Os arquétipos e o inconsciente coletivo. Petrópolis, RJ: Vozes, $7^{\mathrm{a}}$ ed, 2011. 458 p.

KRZNARIC, R. O poder da empatia: a arte de se colocar no lugar do outro para transformar o mundo. Rio de Janeiro: Zahar, 2015. 272.

MAFESOLI, M. O mistério da Conjunção. Ensaios sobre comunicação, corpo e linguagem. Porto Alegre: Sulina, 2009.

OSWALD, J. The Cry of Nature; An Appeal to Mercy and to Justice on Behalf of the Persecuted Animals. Mellen Animal Rights Library, v. 8. Lewiston, Nova Iorque: Edwin Mellen Pr, 2000. 70 p.

PERLS, F. A abordagem gestáltica e testemunha ocular da terapia. Rio de Janeiro: Zahar, 1981. $212 \mathrm{p}$.

PIAGET, J. Seis estudos de Psicologia. Tradução: Maria Alice Magalhães D’Amorim e Paulo Sérgio Lima Silva. Rio de Janeiro: Forense Universitária, 2009. 136 p.

PINKER, S. O instinto da linguagem: como a mente cria a linguagem. São Paulo: Martins Fontes, 2002. $628 \mathrm{p}$.

PIRES, M. T. "Não é mais possível dizer que não sabíamos”, diz Philip Low. Veja.com. 16 jul. 2012. Disponível em: <http://veja.abril.com.br/ciencia/nao-e-mais-possivel-dizer-que-nao-sabiamos-dizphilip-low/>. Acesso em 27 abr. 2017.

ROBERTS, M. O homem que ouve cavalos. São Paulo: Bertrand Brasil, 2001. 343 p. 